\title{
Plant height and seed yield of castor (Ricinus communis L.) sprayed with growth retardants and harvest aid chemicals
}

\author{
J.S. Oswalt ${ }^{\mathrm{a}, \mathrm{b}}$, Jacob M. Rieff ${ }^{\mathrm{a}, \mathrm{c}}$, Liv S. Severino ${ }^{\mathrm{a}, \mathrm{d}, *}$, Dick L. Auld ${ }^{\mathrm{a}, \mathrm{e}}$, \\ Craig W. Bednarz $^{\mathrm{b}}$, Glen L. Ritchie ${ }^{\mathrm{a}}$ \\ a Department of Plant and Soil Science, Texas Tech University, Lubbock, TX 79409, USA \\ b Bayer CropScience, Lubbock, TX 79329, USA \\ c PhytoGen Cottonseed, Lubbock, TX 79423, USA \\ d Embrapa Algodão, Campina Grande 58428-095, PB, Brazil \\ e Texas AgriLife Research, Lubbock, TX 79403 USA
}

\section{A R T I C L E I N F O}

\section{Article history:}

Received 20 April 2014

Received in revised form 18 June 2014

Accepted 1 July 2014

\section{Keywords:}

Mepiquat

Cyclanilide

Pyraflufen

Paraquat

Thidiazuron

Etephon

\begin{abstract}
A B S T R A C T
The perennial growth habit of castor plants (Ricinus communis L.) limits mechanical harvest because the plant grows very tall when the environmental conditions are favorable and produces many immature fruits, fresh stems, and green leaves at harvest time. There is a demand for chemicals that prevent excessive growth and defoliate the plant to prepare the crop to be harvested. This study had the objective of evaluating two growth retardants and three harvest aids (desiccants and defoliants) applied on castor crop at different times and doses. The experiments were conducted in Lubbock, TX, USA from 2007 to 2010. The growth retardants were Pix ${ }^{\circledR}$ (mepiquat chloride) and Stance ${ }^{\circledR}$ (mepiquat chloride + cyclanilide) applied one time at five development stages. The harvest aids were ET $^{\circledR}$ (pyraflufen), Ginstar ${ }^{\circledR}$ (thidiazuron + diuron) + Finish $^{\circledR}$ (etephon + cyclanilide), and paraquat. The growth retardant Pix $^{\circledR}$ promoted rather than inhibited the vertical growth of castor plants, but in general, this product did not influence the seed yield. Stance ${ }^{\circledR}$ did not influence vertical growth, but increased doses were associated with higher castor seed yields. The effect of Stance ${ }^{\circledR}$ on seed yield was more intensive when applied from the 8th node stage through the first expanded leaf after the primary inflorescence. Early termination caused seed yield reduction compared with frost-killed plants, but the loss was progressively diminished as the termination occurred later in the season. There were differences in the effect of harvest aids. The reduction of mean seed yield caused by paraquat was not significant, but ET ${ }^{\circledR}$ and Ginstar $^{\circledR}+$ Finish $^{\circledR}$ reduced the mean seed yield compared with untreated plants.
\end{abstract}

(C) 2014 Elsevier B.V. All rights reserved.

\section{Introduction}

Most of the present global production of castor (Ricinus communis L.) is hand-harvested in the main producing countries (India, China, and Brazil). The production of castor is being limited by the lack of technology for a fully mechanized cropping system (Severino et al., 2012). Mechanical harvesting is challenging because this plant can grow very tall due to its perennial growth habit. The main problems for mechanical harvest are the presence

Abbreviations: MC, mepiquat chloride; PGR, plant growth regulator.

* Corresponding author at: Embrapa Algodão, Rua Oswaldo Cruz, 1143, 1811, Campina Grande

E-mail addresses: liv.severino@embrapa.br, liv.severino@gmail.com (L.S. Severino). of green leaves and immature fruits at harvesting time and the persistent growth when environmental conditions are favorable. The problem with plant height can be partially overcome with the adoption of dwarf castor varieties, but growth retardants are also necessary when environmental conditions are excessively favorable to plant growth or when cultivars with the dwarf trait are not available.

Plant growth regulators (PGR) are products largely employed in agriculture to influence specific aspects of plant growth and development, and harvest aids are used to induce a faster defoliation, desiccation, fruit maturation, and regrowth suppression (Logan and Gwathmey, 2002). In castor, there is demand for PGR that reduce vertical growth and for harvest aids that induce leaf abscission, reduce moisture in the stem, and suppress regrowth prior to harvesting. Most growth retardants act by interfering with hormone concentrations, such as inhibiting gibberellin 
biosynthesis or auxin transport (Rademacher, 2000; Burton et al., 2008). Growth retardants are expected to reduce plant growth without being phytotoxic or affecting seed yield.

There is limited literature on the effect of PGR in castor crop. It was observed that mepiquat chloride (MC) was not effective in reducing castor plant growth (Campbell et al., 2014), but when applied to the seed (soaking) prior to sowing, it reduced plant height without interfering with germination, seedling vigor, and root growth. However, it did affect other aspects of plant growth and physiology such as leaf area, chlorophyll content, shoot dry weight, and sugar and starch content (Rigon et al., 2011; Oliveira et al., 2008; Rodrigues et al., 2008; Capuani et al., 2012).

Mepiquat chloride, an active ingredient of Pix ${ }^{\circledR}$ and Stance ${ }^{\circledR}$ is a growth retardant extensively used in cotton (Reddy et al., 1995; Rademacher, 2000). It acts as an inhibitor of gibberellins biosynthesis, which is a hormone that promotes cell elongation. With reduced concentration of gibberellins, there is less elongation of cells in the stem, and the vertical growth is reduced. However, as a side effect, mepiquat chloride can interfere with the concentration of other plant hormones such as cytokinins, ethylene, and abscisic acid, which can affect other physiological processes (Rademacher, 2000).

Cyclanilide is one of the active ingredients of Stance ${ }^{\circledR}$, which is a PGR labeled for use in cotton at different stages of growth. It acts by inhibiting auxin transport (Burton et al., 2008), what causes reduction in the concentration of this hormone in the site of action. It is always used in combination with other PGR (Burton et al., 2008). When used in combination with growth retardants, the gibberellins activity is further reduced because the low auxin content interferes with the activity of auxin-dependent enzymes that activate gibberellins (Burton et al., 2008). When used in combination with ethylene promoters (like Etephon ${ }^{\circledR}$ ), cyclanilide enhances the defoliation effect because leaf abscission is regulated by the balance between ethylene (abscission promoter) and auxin (abscission inhibitor). Thus, cyclanilide reduces the auxin concentration, while Etephon ${ }^{\circledR}$ increases the ethylene concentration (Burton et al., 2008; Pedersen et al., 2006). For instance, a concentration of $0.067 \mathrm{~kg} \mathrm{ha}^{-1}$ of ethephon did not defoliate common bean (Phaseolus vulgaris L.) in the absence of cyclanilide, but it did in its presence (Pedersen et al., 2006). Cyclanilide used alone causes a different effect. It was found to block apical dominance, enhance lateral branching, and cause a slight reduction in vertical growth in apple (Malus domestica Borkh), sweet cherry (Prunus avium), and common bean (Elfving and Visser, 2005, 2006; Pedersen et al., 2006).

Harvest aids are chemical products used to induce specific plant responses and prepare the crop for harvest (Gwathmey and Hayes, 1997; Du et al., 2013). The effects of harvest aids include: defoliation, desiccation, fruit maturation, and inhibition of regrowth. Most desiccants are contact herbicides that act directly on leaf cells, while defoliants interfere with the concentration of endogenous hormones such as ethylene and abscisic acid (Biles and Cothren, 2001) that cause leaf abscission.

The mode of action is different among the harvest aids. The active ingredients of Ginstar ${ }^{\circledR}$ are thidiazuron and diuron. Thidiazuron is a synthetic hormone with cytokinin-like activity that induces premature leaf abscission by activating the leaf abscission layer as result of the change in the ethylene to auxin ratio (Du et al., 2013). It is often used in association with diuron, particularly under cool temperatures. Diuron is a contact herbicide that damages the photosystem II and prevents photosynthesis. The active ingredients of Finish ${ }^{\circledR}$ are etephon and cyclanilide (which was prevo=iously discussed as a plant growth regulator). Etephon is an ethylene precursor that can induce both defoliation and fruit maturation, like the boll-opening effect observed in cotton (Stewart et al., 2000; Du et al., 2013). The active ingredient of $\mathrm{ET}^{\circledR}$ is pyraflufen-ethyl, which is a contact herbicide that acts inhibiting the enzyme protoporphyrinogen oxidase (Protox). It causes rapid desiccation of foliage in the presence of light. It is labeled as harvest aid in potato (Solanum tuberosum) and cotton (Griffin et al., 2010; Ivany, 2005; Miura et al., 2003), which is a perennial tropical plant like castor. Paraquat is a broad-spectrum herbicide that inhibits photosynthesis at Photosystem I and causes defoliation (Griffin et al., 2010). In cotton, paraquat is also used to improve boll opening when drying conditions are not favorable to fruit dehiscence (Stewart et al., 2000).

This study had the objective of evaluating the effect on castor plant height and seed yield of two plant growth regulators and three harvest aids applied at different stages of crop development.

\section{Material and methods}

The experiments were conducted at the Experimental Farm of Texas Tech University (Lubbock, TX, USA, 333' $\mathrm{N}, 101^{\circ} 53^{\prime} \mathrm{W}$, $990 \mathrm{~m}$ asl). Irrigation was applied with a subsurface drip irrigation system, with tapes spaced $1 \mathrm{~m}$ apart and buried $0.3 \mathrm{~m}$ below the soil surface and emitters located at every $0.60 \mathrm{~m}$. The amount of water supplied to the plants was $123 \mathrm{~mm}$ of irrigation plus $314 \mathrm{~mm}$ of rain in 2007, $82 \mathrm{~mm}$ of irrigation plus $552 \mathrm{~mm}$ of rain in 2008 , $144 \mathrm{~mm}$ of irrigation plus $236 \mathrm{~mm}$ of rain in 2009, and $218 \mathrm{~mm}$ of irrigation plus $259 \mathrm{~mm}$ of rain in 2010 . The plots were sown with a mechanical planter in May of each year, just after the soil reached temperatures between 18 and $20^{\circ} \mathrm{C}$. Nitrogen fertilizer (urea) was applied in the dose of $32 \mathrm{~kg} \mathrm{ha}^{-1}$ of $\mathrm{N}$ through irrigation water at 30 days after emergence. Sprayings of the chemicals were made with a Lee Spider Sprayer equipped with a four row multi-boom using $\mathrm{CO}_{2}$ as a propellant to achieve the optimum spraying pressure of 2.75 bars. A total spray volume of $935 \mathrm{Lha}^{-1}$ was applied using Teejet TP8003 tips.

\subsection{Plant growth regulators}

The experiments were conducted from 2007 to 2009 with the cultivar Hale, a semi-dwarf genotype selected in West Texas, USA (Brigham, 1970). The planter was adjusted to deliver six seeds per meter. Treatments consisted of a control and a factorial distribution of two PGR applied at three doses and at five stages of plant development. The PGR were Pix ${ }^{\circledR}$ (mepiquat chloride-1,1-dimethylpiperidinium chloride) and Stance ${ }^{\circledR}$ (mepiquat chloride + cyclanilide-1-(2,4-dichloroanilinocarbonyl) cyclopropanecarboxylic acid). The doses of both products were $0.38,0.51$, and $0.73 \mathrm{~L} \mathrm{ha}^{-1}$ applied at one time. The doses were in the range of rates commonly recommended for cotton crop. Sprayings were made in the following stages of development: (i) expanding leaf in the 6th node of the primary stem, (ii) expanding leaf on the 8th node of the primary stem, (iii) appearance of the first inflorescence, (iv) one expanding leaf in a secondary stem after the appearance of the first inflorescence, and (v) appearance of the second inflorescence. The experiment in 2007 did not include $\mathrm{Pix}^{\circledR}$, and the spraying at the stage of 6th node in 2009 was not performed because of excessive rains during the period.

Plots were arranged in a completely randomized design with four replications. Experimental plots consisted of four rows 10-m long and spaced by $1 \mathrm{~m}$ between rows. Data was taken in the two middle rows of each plot after the killing frost that occurred around the last week of October. Plant height was measured in ten consecutive plants in each central row. The fruits in the plants in a $1-\mathrm{m}$ segment of each central row were harvested. The fruits were dehulled in an Agriculex SPI-1 belt thresher, and the seed yields were calculated from the seed weight. 


\subsection{Harvest aids}

The experiments were conducted in 2009 and 2010. The cv. AL Guarany was tested in 2009, the cv. Brigham was tested in 2010, and the cv. Hale was tested in both years. The cv. AL Guarany is a medium-height plant selected in Brazil (Freire et al., 2001). The cv. Brigham is a medium-height plant selected as the first commercial variety with reduced ricin content (Auld et al., 2001).

The experiment was planted in a completely randomized block design with four replications. The experimental plot consisted of four $6-\mathrm{m}$ long rows spaced by $1 \mathrm{~m}$. The experiments were sown in 11 May 2009 and 7 May 2010 in the spacing of $0.5 \mathrm{~m}$ between plants. The treatments consisted of three harvest aids applied at three different times along the growing season. The harvest aids and doses were: (i) ET $^{\circledR}$ (pyraflufen ethyl 2.5\% of a.i) in the dose of $0.081 \mathrm{~L} \mathrm{ha}^{-1}$, (ii) Ginstar ${ }^{\circledR}$ (thidiazuron $12 \%$ of a.i. plus diuron $6 \%$ of a.i.) in the dose of $0.21 \mathrm{~L} \mathrm{ha}^{-1}$ tank-mixed with Finish ${ }^{\circledR}$ (etephon $32.1 \%$ of a.i. plus cyclanilide $4.3 \%$ of a.i.) in the dose of $0.71 \mathrm{~L} \mathrm{ha}^{-1}$, and (iii) paraquat in the dose of $0.62 \mathrm{~L} \mathrm{ha}^{-1}$. The application times were: (i) early September (1 Sep 2009 and 10 Sep 2010), (ii) mid September (15 Sep 2009 and 21 Sep 2010), and (iii) early October (1 Oct 2009 and 11 Oct 2010). Untreated frost-killed plants were used as check treatment. The seed samples for measuring productivity were taken after the killing frost, which occurred around the last week of October. The fruits in the plants in a 1-m segment of each central row were harvested. The fruits were dehulled in an Agriculex SPI-1 belt thresher, and the seed yields were calculated from the seed weight.

\subsection{Statistical procedures}

The significance level of 0.05 was adopted for all the analysis. The cropping season was assumed as a random effect, and the data obtained in different years were pooled. In the comparison of qualitative variables, the means were compared only with the respective control treatment using F-test and contrasts. The difference in the means of the two PGR (Stance ${ }^{\circledR}$ and Pix ${ }^{\circledR}$ ) was not tested because they were planted in different areas and dates. The dose-dependent effect of each PGR across years was analyzed with multiple linear regression, and the slope significance was tested by $t$ test. For the regression analysis, all the data points were pooled across years and spraying time. In the graphs, only the mean value, the standard error of the mean (as vertical bars), the regression line, the equation, and the $R^{2}$ were presented. When the slope was not significant, the regression line was omitted. The data on castor mean seed yield measured in the experiment on harvest aids $\left(\right.$ ET $^{\circledR}$, Ginstar $^{\circledR}+$ Finish $^{\circledR}$, and paraquat) were compared only with the check treatment (frost killed plants) using contrasts and F-test.

\section{Results}

\subsection{Plant height and seed yield}

Stance ${ }^{\circledR}$ did not influence the vertical growth (Fig. 1), but it promoted an increased seed yield (Fig. 2), particularly when applied in the stages between the 8th node and an expanded leaf after the first inflorescence (Table 1). The seed yield was significantly increased in response to increments in the dose of Stance (Fig. 2). Pix ${ }^{\circledR}$ promoted the vertical growth of castor plants, which is the opposite of the expected result. Higher doses of Pix ${ }^{\circledR}$ were associated with taller plants (Fig. 1), but that effect was not associated with the spraying time (Table 1). However, Pix ${ }^{\circledR}$ did not influence the seed yield, except when applied at the 8 th node stage, in which the mean seed yield was significantly higher than the untreated plants. The
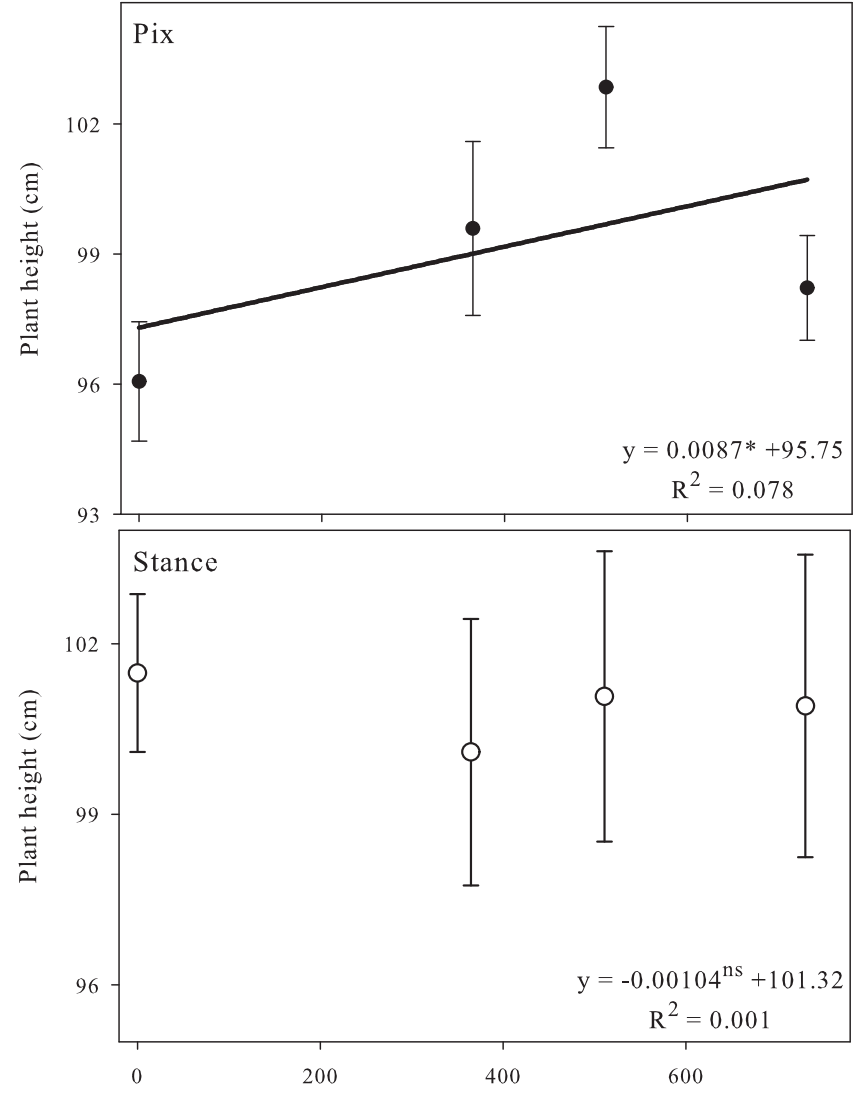

Dose of the Plant Growth Regulator $\left(\mathrm{L} \mathrm{ha}^{-1}\right)$

Fig. 1. Castor plant height in response to doses of $\mathrm{Pix}^{\circledR}$ (mepiquat chloride) and Stance ${ }^{\circledR}$ (mepiquat chloride + cyclanilide) in Lubbock, TX, USA. Each point is a mean across years and spraying time. The vertical bars are the standard error of the mean.

effects of PGRs were erratic if analyzed in each year (data not presented). For example, Stance ${ }^{\circledR}$ was effective in reducing castor plant height in 2007 (a dose-dependent response), and Pix ${ }^{\circledR}$ promoted an increased seed yield in 2009. However, those effects were not repeated across years, and the analysis with pooled data resulted insignificant.

Table 1

Plant height and seed yield in response to doses of Stance ${ }^{\circledR}$ (mepiquat chloride + cyclanilide) and Pix ${ }^{\circledR}$ (mepiquat chloride) applied to castor cv. Hale at different development stages at Lubbock, TX, USA in three cropping seasons (2007-2009).

\begin{tabular}{|c|c|c|}
\hline & Stance $^{\circledR}$ & $\operatorname{Pix}^{\circledR}$ \\
\hline & Plant height $(\mathrm{cm})$ & \\
\hline Node 6 & $102.6^{\mathrm{ns}}$ & $99.6^{\text {ns }}$ \\
\hline Node 8 & $100.5^{\mathrm{ns}}$ & $101.4^{\mathrm{ns}}$ \\
\hline First inflorescence & $98.8^{\text {ns }}$ & $99.6^{\mathrm{ns}}$ \\
\hline After first inflorescence & $101.3^{\text {ns }}$ & $98.0^{\mathrm{ns}}$ \\
\hline Second flower & $100.8^{\mathrm{ns}}$ & $102.2^{\text {ns }}$ \\
\hline Untreated (control) & $\begin{array}{l}101.5 \\
\text { seed yield }\left(\mathrm{kg} \mathrm{ha}^{-1}\right)\end{array}$ & 96.1 \\
\hline Node 6 & $2544^{\mathrm{ns}}$ & $2616^{\mathrm{ns}}$ \\
\hline Node 8 & $3045^{*}$ & $3261^{*}$ \\
\hline First inflorescence & $2901^{*}$ & $2970^{\text {ns }}$ \\
\hline After first inflorescence & $2964^{*}$ & $3042^{\text {ns }}$ \\
\hline Second flower & $2776^{\mathrm{ns}}$ & $2856^{\text {ns }}$ \\
\hline Untreated (control) & 2635 & 2830 \\
\hline
\end{tabular}

$*$ and ${ }^{\mathrm{ns}}$ : the difference of the mean is, respectively, significant $(p=0.05)$ or not significant compared with the untreated plants when analyzed by contrast and $F$-test. The data was pooled across years and rates. 


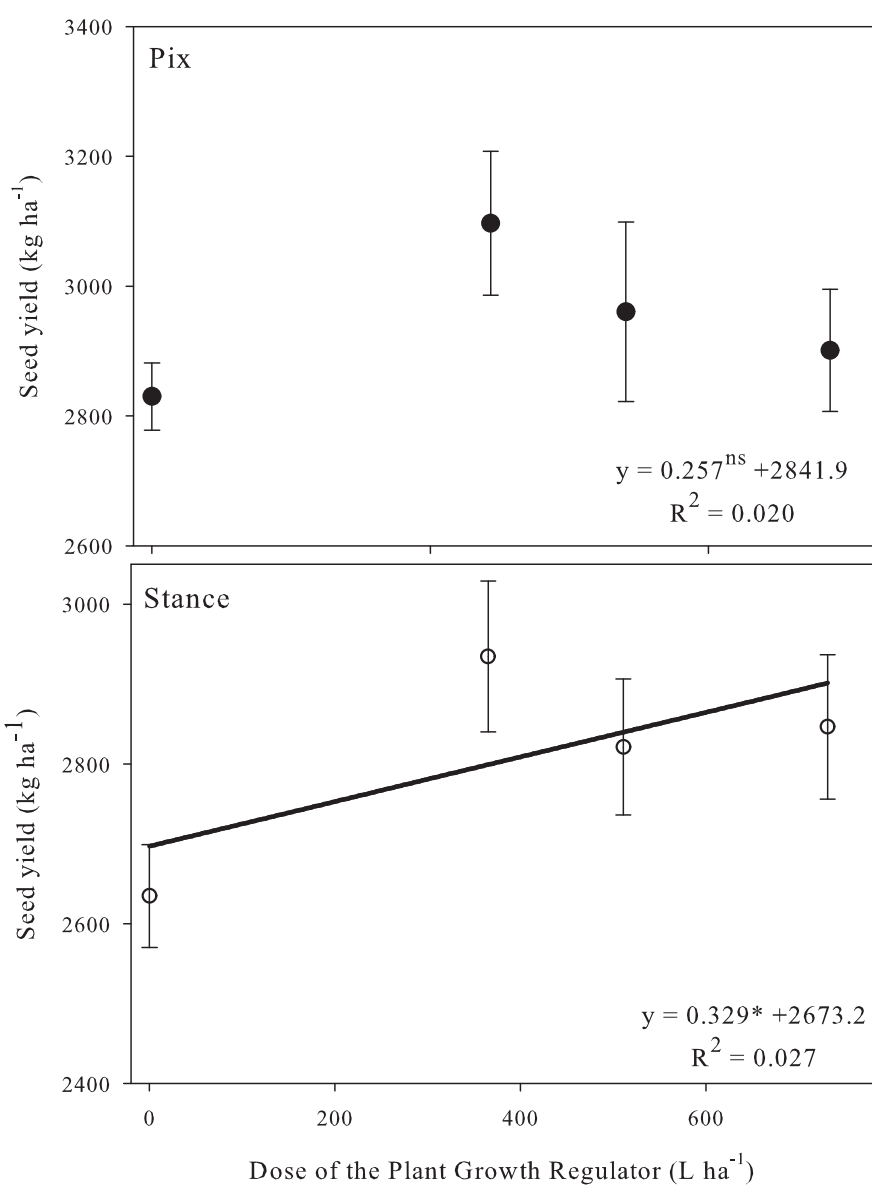

Fig. 2. Castor seed yield in response to doses of $\mathrm{Pix}^{\circledR}$ (mepiquat chloride) and Stance ${ }^{\circledR}$ (mepiquat chloride + cyclanilide) in Lubbock, TX, USA. Each point is a mean across years and spraying time. The vertical bars are the standard error of the mean.

\subsection{Crop termination influencing seed yield}

Termination of the crop at early September caused a $24 \%$ reduction in castor mean seed yield compared with the frost-killed plants (2226 compared with $2925 \mathrm{~kg} \mathrm{ha}^{-1}$ ) (Table 2). The seed yield loss was progressively diminished as the termination occurred later in the season, although there was no significant loss when the spraying was performed at early October. The early termination causing seed yield reduction was confirmed in all three cultivars, except in the cv. AL Guarany sprayed at mid-September, in which the reduction was not significant $(p=0.420)$.

There were differences in the seed yield among the harvest aids. The mean seed yield of the plants treated with $\mathrm{ET}^{\circledR}\left(2289 \mathrm{~kg} \mathrm{ha}^{-1}\right)$ and Ginstar ${ }^{\circledR}+$ Finish $^{\circledR}\left(2390 \mathrm{~kg} \mathrm{ha}^{-1}\right)$ were significantly lower than the control (2925 $\left.\mathrm{kg} \mathrm{ha}^{-1}\right)$, while the mean seed yield in the plants treated with paraquat were not significantly different of the frostkilled plants (Table 2). The mean seed yield of the cv. Hale and Brigham was negatively affected by $\mathrm{ET}^{\circledR}$ and Ginstar ${ }^{\circledR}+$ Finish $^{\circledR}$. The mean seed yield of cv. AL Guarany was not affected by any of the harvest aids (Table 2 ).

\section{Discussion}

\subsection{Growth retardants}

Historically, the results of PGR spraying on plant growth and seed yield have been erratic because under field conditions their effect is dependent not only on its biochemical potential, but also on factors such as plant responsiveness, uptake, translocation, and persistency (Rademacher, 2000; Stewart et al., 2000). For that reason, there is not a precise recommendation of time and rate of application (Reddy et al., 1995). The sensitiveness to PGRs is different among species. For example, the growth regulation effect of mepiquat chloride in wheat (Triticum sativum L.) requires a dose 20 -fold higher than the dose required in cotton (Gossypium hirsutum), and some species can be virtually insensitive to this retardant (Rademacher, 2000).

Under specific conditions, the PGRs are effective on castor crop, as observed in 2007, when Stance ${ }^{\circledR}$ reduced plant height, and in 2009, when Pix ${ }^{\circledR}$ increased seed yields (data not presented). However, there is not enough understanding on the environmental or physiological factors that influence the response. $\mathrm{Pix}^{\circledR}$ was found to be effective to reduce castor plant growth when applied to the seed (by soaking prior to sowing) (Capuani et al., 2012; Rodrigues et al., 2008; Rigon et al., 2011), and it influenced the male to female ratio when sprayed on castor leaves (Severino et al., 2006). The same effect of Pix ${ }^{\circledR}$ promoting (instead of suppressing) vertical growth of castor plants was observed by Beltrão et al. (2010), while Campbell et al. (2014) did not observe the effect of this PGR on castor plants growth.

Further studies will be necessary to understand the factors that influence the effect of Pix ${ }^{\circledR}$ and Stance ${ }^{\circledR}$ on castor plants at field conditions. Some hypothesis are that: (i) the thick leaf cuticle of castor leaf reduces the absorption of the PGR, (ii) the PGR is washed (by rain) or dries in the leaf surface before it is absorbed into the leaf, and (iii) the PGR prevents growth for a short period, but the growth is compensated later when environmental conditions remain favorable.

As observed in this experiment, erratic results of PGR are frequently observed in other crops (Rademacher, 2000; Stewart et al., 2000; Reddy et al., 1995; Dodds et al., 2010), and they are actually a challenge for farmers because they depend on these products for managing the plant height, but there is no protocol describing time and rates of application.

In this study, the PGR were applied as a one-time dose, at a specific development stage. However, multiple applications along the phase of intensive plant growth (before the onset of the reproductive growth) is an effective strategy adopted in cotton (Dodds et al., 2010) that allows flexibility in the dose to be applied and some adjustments at late stages in the cases that early applications failed to control plant growth.

Although the PGR are not intended to directly influence seed yields, in some cases the productivity is favored because less photosynthates are allocated to stem vertical growth, plant architecture become more adequate for light capturing, or problems with pests and diseases are diminished (Nuti et al., 2006; Dodds et al., 2010). In this experiment, the PGRs were more efficient for increasing seed yield than for reducing vertical growth (Table 1 ).

\subsection{Harvest aids}

Because of the tropical origin of castor plants, the seed fill is very slow in the cool temperatures observed in the months of September and October in the region where the study was conducted. The fruit maturation is fast in August, slow in September, and negligible in October (Severino and Auld, 2013, 2014). Considering that it is expected to have little increase in the seed yield in the last two months of the growing season (because of thermal restriction), the farmers have advantages with an early termination of the crop, such as reduced loss of seeds due to fruit shatter and optimization of the use of land and harvesting machinery.

The results of this study confirm that the later the crop is terminated, the higher is the seed yield (Table 2). Early termination associated with reduced productivity was observed in lesquerella (Lesquerella fendleri) (Coates, 1996), cotton (Çopur et al., 2010), and 
Table 2

Seed yield of castor plants defoliated with four harvest aids sprayed at different time in two cropping seasons (2009 and 2010) in Lubbock, TX, USA.

\begin{tabular}{|c|c|c|c|c|c|}
\hline & & AL Guarany & Brigham & Hale & Mean \\
\hline & & \multicolumn{4}{|c|}{ seed yield $\left(\mathrm{kg} \mathrm{ha}^{-1}\right)$} \\
\hline \multirow[t]{4}{*}{ Spraying time } & Frost killed (control) & 1952 & 3467 & 3072 & 2925 \\
\hline & Early September & $1328 *$ & $2728^{*}$ & $2425^{*}$ & $2226^{*}$ \\
\hline & Mid-September & $1697^{\mathrm{ns}}$ & $2743^{*}$ & $2578^{*}$ & $2436^{*}$ \\
\hline & Early October & $2048^{\mathrm{ns}}$ & $2844^{*}$ & $3071^{\text {ns }}$ & $2787^{\mathrm{ns}}$ \\
\hline \multirow[t]{3}{*}{ Harvest aid } & $\mathrm{ET}^{\circledR 1}$ & $1667^{\mathrm{ns}}$ & $2503^{*}$ & $2455^{*}$ & $2289^{*}$ \\
\hline & Ginstar $^{\circledR 2}+$ Finish $^{\circledR 3}$ & $1462^{\text {ns }}$ & $2787^{*}$ & $2595^{*}$ & $2390^{*}$ \\
\hline & Paraquat & $1834^{\mathrm{ns}}$ & $3026^{\text {ns }}$ & $2988^{\text {ns }}$ & $2736^{\mathrm{ns}}$ \\
\hline
\end{tabular}

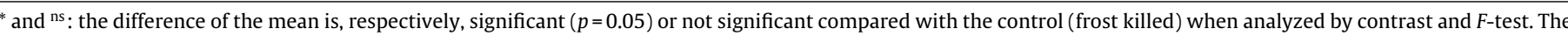
data was pooled across years and spraying time or product.

1 Pyraflufen ethyl.

2 Thidiazuron + diuron.

${ }^{3}$ Etephon + cyclanilide.

soybean (Glycine max) (Griffin et al., 2010). Some weeks prior to harvest, the expected increase in seed weight can be estimated considering the amount of immature fruits and the anticipated degree-days before the frost calculated with the base temperature of $15^{\circ} \mathrm{C}$ (Severino and Auld, 2014).

The products used for desiccation and defoliation had different effect on castor seed yield. The performance of harvest aids in many crops is inconsistent, and the results unpredictable (Logan and Gwathmey, 2002). This erratic effect occurs because these chemicals those chemical have different mechanisms of action, and they are highly influenced by environmental condition prevailing before and after the treatment. For instance, Ethephon ${ }^{\circledR}$ can be very effective for inducing defoliation under cool temperature but not in warm temperature regimes (Gwathmey and Hayes, 1997). Ethephon is very sensitive to temperature, and the defoliation of common bean plants under cool temperature required either a higher dose or the combination with cyclanilide (Pedersen et al., 2006). The rate of cotton boll opening following spraying with several harvest aids was the closest associate to the thermal time than to the number of days following application (Stewart et al., 2000). The efficacy of harvest aids is influenced by weather components prevailing two weeks prior and after the spraying (such as air humidity, wind speed, cloudiness, and rains), and even the environmental conditions to which the plants were exposed along the season can influence the results (Logan and Gwathmey, 2002). There are varietal differences in the sensibility to PGR, as observed among cultivars of potato sprayed with pyraflufen-etyl (Ivany, 2005).

The harvest aid is expected to cause the minimal reduction in seed yield and to effectively prepare the plant for harvest. The smallest impact on the mean seed yield was found with paraquat, and that difference was consistent in the three spraying time and among the cultivars (data not presented). Paraquat was found to be effective for defoliating castor crop as fast as four days after spraying (Campbell et al., 2014).

Further studies on the use of harvest aids in castor crop should pay attention to other effects of the chemicals in addition to the influence on seed yield. For instance, significant differences among harvest aids were observed by Trostle and Wallace (2012) and Campbell et al. (2014) in the ability to promote defoliation and suppress regrowth in castor plants. Environmental conditions must also be considered in the studies because they are part of the reason for unpredictable results that are commonly observed in other crops.

\section{Conclusions}

The growth retardant $\mathrm{Pix}{ }^{\circledR}$ promoted increased vertical growth and did not influence castor seed yield. Stance ${ }^{\circledR}$ was not effective in reducing castor plant height, but it promoted increased seed yield when applied at specific growth stages. The early termination of the crop caused seed yield reduction when compared with the frostkilled plants, but the reduction was progressively smaller as the termination occurred later in the season. The minimal seed yield reduction was observed when the crop was sprayed with paraquat, and larger reductions were found in response to the use of $\mathrm{ET}^{\circledR}$ and Ginstar $^{\circledR}+$ Finish $^{\circledR}$.

\section{References}

Auld, D.L., Rolfe, R.D., McKeon, T.A., 2001. Development of castor with reduced toxicity. J. New Seeds 3, 61-69.

Biles, S., Cothren, J.T., 2001. Flowering and yield response of cotton to application of mepiquat chloride and PGR-IV. Crop Sci. 41, 1834-1837.

Beltrão, N.E.M., Alves, G.S., Brito Neto, J.F., Sampaio, L.R., Freire, M.A.O., Silva, F.V.F. 2010. Resposta da mamoneira a aplicação de doses de regulador de crescimento. In: Proceeding of the Congresso Brasileiro de Mamona, p. 4.

Brigham, R.D., 1970. Registration of castor variety Hale. Reg. No. 3. Crop Sci. 10

Burton, J.D., Pedersen, M.K., Coble, H.D., 2008. Effect of cyclanilide on auxin activity. J. Plant Growth Regul. 27, 342-352.

Campbell, D.N., Rowland, D.L., Schnell, R.W., Ferrel, J.A., 2014. Developing a castor (Ricinus communis L.) production system in Florida, U.S.: evaluating crop phenology and response to management. Ind. Crops Prod. 53, 217-227.

Capuani, S., Rigon, J.P.G., Brito, Neto J.F., Beltrão, N.E.M., Rigon, C.A.G., 2012. Crescimento inicial de mamoneira em função do cloreto de mepiquat e adubação nitrogenada em cobertura. In: Proceeding of the Congresso Brasileiro de Mamona, p. 4.

Coates, W., 1996. Effect of harvest method and date on lesquerella seed yields. Ind. Crops Prod. 5, 125-132.

Copur, O., Demirel, U., Polat, R., Gür, M.A., 2010. Effect of different defoliants and application times on the yield and quality components of cotton in semi-arid conditions. Afr. J. Biotechnol. 9, 2095-2100.

Dodds, D.M., Banks, J.C., Barber, L.T., Boman, R.K., Brown, S.M., Edmisten, K.L., Faircloth, J.C., Jones, M.A., Lemon, R.G., Main, C.L., Monks, C.D., Norton, E.R., Stewart, A.M., Nichols, R.L., 2010. Beltwide evaluation of commercially available plant growth regulators. J. Cotton Sci. 14, 119-130.

Du, M.W., Ren, X.M., Tian, X.L., Duan, L.S., Zhang, M.C., Tan, W.M., Li, Z.H., 2013. Evaluation of harvest aid chemical for the cotton-winter wheat double cropping system. J. Integr. Agric. 12, 273-282.

Elfving, D.C., Visser, D.B., 2005. Cyclanilide induces lateral branching in apple trees. Hortscience 40, 119-122.

Elfving, D.C., Visser, D.B., 2006. Cyclanilide induces lateral branching in sweet cherry trees. Hortscience 41, 149-153.

Freire, E.C., Lima, E.F., Andrade, F.P. 2001. Melhoramento genético, In: Azevedo, D.M.P., Lima, E.F. (Eds.), O agronegócio da mamona. Embrapa Algodão/Embrapa Informação Tecnológica, Campina Grande, Brasília, pp. 229-256.

Griffin, J.L., Boudreaus, J.M., Miller, D.K., 2010. Herbicides as harvest aids. Weed Sci. 58, 355-358.

Gwathmey, C.O., Hayes, R.M., 1997. Harvest aid interactions under different temperature regimes in field-grown cotton. J. Cotton Sci. 1, 1-28.

Ivany, J.A., 2005. Response of three potato (Solanum tuberosum) cultivars to pyraflufen-ethyl used as desiccant in Canada. Crop Prot. 24, 836-841.

Logan, J., Gwathmey, C.O., 2002. Effects of weather on cotton response to harvest-aid chemicals. J. Cotton Sci. 6, 1-12

Miura, Y., Mabuchi, T., Higashimura, M., Amanuma, T., 2003. Development of a new herbicide, pyraflufen-ethyl. J. Pestic. Sci 28, 219-220.

Nuti, R.C., Viator, R.P., Casteel, S.N., Edmisten, K.L., Wells, R., 2006. Effect of planting date, mepiquat chloride, and glyphosate application to glyphosate-resistant cotton. Agron. J. 98, 1627-1633.

Oliveira, M.I.P., Lucena, A.M.A., Tavares, M.J.V., Brito, G.G., Lima, V.L.A., Beltrão N.E.M., 2008. Conteúdo de açúcares e amido em folhas de mamoneira oriundas 
de sementes tratadas com cloreto de mepiquat. In: Proceedings of the Congresso Brasileiro de Mamona, p. 3.

Pedersen, M.K., Burton, J.D., Coble, H.D., 2006. Effect of cyclanilide, etephon, auxin transport inhibitors, temperature on whole plant defoliation. Crop Sci. 46, $166-1672$.

Rademacher, W., 2000. Growth retardants: Effects on gibberellin biosynthesis and other metabolic pathways. Annu. Rev. Plant Physiol. Mol. Biol. 51, 501-531.

Reddy, K.R., Boone, M.L., Reddy, A.R., Hodges, H.F., Turner, S.B., McKinion, J.M., 1995 Developing and validating a model for a plant growth regulator. Agron. J. 87, 1100-1105.

Rigon, J.P.G., Beltrão, N.E.M., Capuani, S., Neto, J.F.B., 2011. Initial growth of the castor bean soaked in mepiquat chloride and nitrogen topdressing fertilization. Rev. Verde Agroecol. Desenvolv. Sustent. 6, 28-33.

Rodrigues, D.M., Oliveira, M.I.P., Freire, M.A.O., Sampaio, L.R., Albuquerque, W.G., Beltrão, N.E.M., 2008. Proceeding of the Congresso Brasileiro de Mamona, vol. 3.

Severino, L.S., Auld, D.L., Baldanzi, M., Cândido, M.J.D., Chen, G., Crosby, W., Tan, D., He, X., Lakshmamma, P., Lavanya, C., Machado, O.L.T., Mielke, T., Milani, M.,
Miller, T.D., Morris, J.B., Morse, S.A., Navas, A.A., Soares, D.J., Sofiatti, V., Wang M.L., Zanotto, M.D., Zieler, H., 2012. A review on the challenges for increased production of castor. Agron. J. 104, 853-880

Severino, L.S., Auld, D.A., 2013. Seed yield and yield components of castor influenced by irrigation. Ind. Crops Prod. 49, 52-60.

Severino, L.S., Auld, D.A., 2014. Study on the effect of air temperature on seed development and determination of the base temperature for seed growth in castor (Ricinus communis L.). Aust. J. Crop Sci. 8, 290-295.

Severino, L.S., Silva, M.I.L., Farias, V.A., Beltrão, N.E.M., Cardoso, G.D., 2006. Sexua expression of castor influenced by fertilizer and mepiquat chloride. Rev. Cienc. Agron. 37, 339-344.

Stewart, A.M., Edmisten, K.L., Wells, R., 2000. Boll openers in cotton: effectiveness and environmental influences. Field Crops Res. 67, 83-90.

Trostle, C.L., Wallace, S., 2012. Harvest aid defoliation and regrowth suppression in castor (Ricinus communis L.) in a semi-arid environment. In: ASA Annual Meeting, Available at https://scisoc.confex.com/crops/2012am/webprogram/ Handout/Paper75401/ASA\%20Castor\%20Harvest\%20Aid\%202012.pdf 